\title{
Clonal analysis of Escherichia coli serotype 06 strains from urinary tract infections*
}

\author{
Gerhard Zingler, ${ }^{1}$ Manfred Ott, ${ }^{2}$ Gabriele Blum, ${ }^{2}$ Ursula Falkenhagen, ${ }^{1}$ \\ Günter Naumann,' Wanda Sokolowska-Köhler ${ }^{3}$ and Jörg Hacker ${ }^{2} \dagger$ \\ 1/nstitut für Medizinische Mikrobiologie, Universität Rostock, Schillingallee 70, D-O 2500 \\ Rostock 1; ${ }^{2}$ Institut für Genetik und Mikrobiologie, Universität Würzburg, Röntgenring 11. \\ $D$-W 8700 Würzburg, and ${ }^{3}$ Institut für Medizinische Mikrobiologie der Humboldt-Universität \\ zu Berlin, Clara-Zetkin-Str. 96, D.O 1040 Berlin, Germany
}

(Received October 14, 1991; accepted in revised form December 17, 1991)

Zingler, G. (Institut für Medizinische Mikrobiologie, Universität Rostock, Schillingallee 70, D-O 2500 Rostock 1, Germany), M. Ott, G. Blum, U. Falkenhagen, G. Naumann, W. SokolowskaKöhler and J. Hacker. Clonal analysis of Escherichia coli serotype 06 strains from urinary tract infections. Microbial Pathogenesis 1992; 12: 299-310.

A total of 36 Escherichia coli urinary tract isolates (UTI) of serotype 06, with different combinations of capsule $(\mathrm{K})$ and flagellin $(\mathrm{H})$ antigens, were analysed according to the outer membrane pattern (OMP), serum resistance properties, mannose-resistant hemagglutination using various types of erythrocytes, and also for the genetic presence and the expression of $\mathrm{P}$. fimbriae. S fimbriae/F1C fimbriae, Type 1 fimbriae, aerobactin and hemolysin. Twenty selected strains were further analysed by pulsed field gel electrophoresis (PFGE), elaborating genomic profiles by $X b a \mid$ cleavage and subsequent Southern hybridization to virulence-associated DNA probes. It could be shown that $06 \mathrm{UTI}$ isolates represent a highly heterogeneous group of strains according to the occurrence and combination of these traits. Relatedness on the genetic and the phenotypic level was found for some of the strains exhibiting the same $\mathrm{O}: \mathrm{K}: \mathrm{H}: \mathrm{F}$ serotype. DNA long-range mapping further indicated some interesting features, according to the copy number and the genomic linkage of virulence genes.

Key words: E. coli serotype 06; urinary tract infection; virulence factors; clonal analysis; molecular epidemiology.

\section{Introduction}

Bacterial infections of the urinary tract encompass a wide spectrum of clinical syndromes, ranging from asymptomatic bacteriuria to symptomatic cystitis and pyelonephritis. A single bacterial species, Escherichia coli, causes more than $80 \%$ of these infections, and neither anatomical differences nor defects in host defense mechanisms provide an adequate explanation for the different clinical patterns that have been observed. ${ }^{1}$ Escherichia coli 06 strains isolated from urinary tract infections often express specific properties that are not prevalent among strains from the commensal fecal flora. These properties include the expression of adhesins mediating attachment to specific receptors on uroepithelial cells, production of hemolysin, serum

- Dedicated to Dr Ida Orskov and Dr Frits Orskov on the occasion of their 70th birthdays.

t Author to whom correspondence should be addressed. 
resistance $(S R)$, release of aerobactin and the presence of particular capsular (K) antigens. $^{2-5}$

The ability to adhere to uroepithelial cells is considered to be a crucial virulence factor which allows certain fecal clones of $E$. coli to colonize the urinary tract. Several adhesins of uropathogenic $E$. coli have been analysed by agglutination assays. Type 1 fimbriae bind to $\alpha$-D-mannose and thereby agglutinate guinea-pig erythrocytes and Saccharomyces cerevisiae cells. ${ }^{6}$ P-fimbrial adhesins recognize specifically the globo series of glycolipids present on both human erythrocytes bearing the $P$ blood group antigen and uroepithelial cells. ${ }^{7}$ The minimal binding receptor of this adhesin type is the disaccharide $\alpha$-D-galactosyl-(1-4)- $\beta$-D-galactopyranose (Gal-Gal). S-fimbrial adhesin binds to sialyl $(\beta 2-3)$ galactosides moieties, present on human and bovine erythrocytes. ${ }^{8.9}$ Fimbriae of serotype $\mathrm{F} 1 \mathrm{C}$ are unable to agglutinate erythrocytes, but do seem to interact with cells of the human urinary tract. ${ }^{10-12}$

Recently we analysed $E$. coli serotype 06 strains, originating from various extraintestinal sources, which were shown to be highly heterogeneous. ${ }^{13}$ Several other groups investigated $E$. coli $\mathrm{O} 6$ isolates $^{14 \cdot 16}$ according to the relation of serotype and genetic and phenotypic diversity, including the analysis of virulence factors. In the light of previous studies, we attempted to analyse serotype 06 isolates from urinary tract infections, in order to get an insight into the correlation of genetic and phenotypic traits with serotype and type of infection, by combining classical and molecular typing methods.

\section{Results}

\section{Serotypes and outer membrane patterns (OMP)}

Among the $36 \mathrm{E}$. coli 06 strains in the collection of uropathogenic isolates, 12 of the strains had complete three-antigen serotypes, resulting in four specific serotypes, 13 had a complete serotype for $\mathrm{O}$ and $\mathrm{K}$ antigens, but were non-motile $\left(\mathrm{H}^{-}\right)$, and 11 had incomplete serotypes, i.e. they lacked a capsular antigen $\left(\mathrm{K}^{-}\right)$or were non-typable for the $\mathrm{K}$ antigen $\left(\mathrm{K}^{+}\right)$. The $06: \mathrm{K}: \mathrm{H}$ serotypes, and the results of most of the tests performed on these strains, are presented in Table 1. Six different OMP patterns associated with these strains were obtained. Thirteen of the 36 strains possessed pattern 1 ; this pattern is typical for strains of serotype $06: \mathrm{K} 53: \mathrm{H} 1,06: \mathrm{K} 2: \mathrm{H} 1$, and $\mathrm{O} 6: \mathrm{K}^{-}: \mathrm{H} 1$. Most other non-motile strains of our collection, except RZ430 and RZ451, had pattern 2, whereas patterns 3, 4, 5, and 6 were found only in a few isolates.

\section{Serum resistance}

Bacteria were also tested for resistance to the bactericidal activity of pooled human serum. $39 \%$ of the strains were serum resistant.

\section{Mannose-resistant hemagglutination (MRHA)}

Various MRHA types were determined on the basis of the hemagglutination (HA) using erythrocytes from different species (human $A_{1}$, pig, bovine, sheep). MRHA of sheep erythrocytes was most common (95\%), followed by HA of pig and bovine erythrocytes $(47 \%)$. Only one-third of our strains showed a MRHA of human erythrocytes. 
DNA-DNA dot blots for the presence of different virulence-associated genes. The phenotypic expression of the corresponding properties was also tested and the results are summarized in Table 1.

P-fimbrial adhesins. One-quarter of the isolates produced adhesins, detectable by binding to $\mathrm{Gal}-\mathrm{Gal}$ receptor molecules ( $P$-specific binding), while $78 \%$ hybridized with a pap (pili associated with pyelonephritis) gene probe. This gene probe shares homology with the $\mathrm{P}$-related sequences $(p r s){ }^{7} \mathrm{P}$-fimbrial adhesins are well expressed

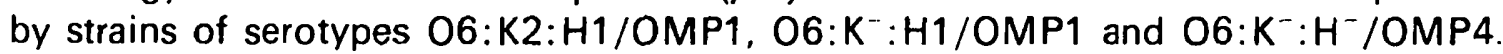
The pap/prs specific gene cluster was also detected on $06: \mathrm{K} 53: \mathrm{H} 1,06: \mathrm{K} 14: \mathrm{H}^{\prime}$, $06: \mathrm{K} 13: \mathrm{H} 1$ and $06: \mathrm{K}^{+}: \mathrm{H} 1$ isolates, but never on $06: \mathrm{K}^{2}: \mathrm{H}^{-1}$ strains of OMP type 2. However, none of these isolates mediates $P$-specific binding and agglutination of sheep erythrocytes indicates the expression of Prs in these strains. Crossed-line immunoelectrophoresis (CLIE) analysis showed that fimbriae of $06: \mathrm{K} 53: \mathrm{H} 1$ and 06:K13:H1 strains causing MRHA of sheep erythrocytes were strongly related serologically to $F 12 / 2$. The fimbrial composition of strains with $P$-receptor binding specificity (Table 1 ) indicated the existence of antigenic heterogeneity among $P$ fimbriae.

S/F1C-fimbrial adhesins. A total of $33(92 \%)$ of the 36 strains were positive in DNADNA dot blots using a gene probe specific for S and F1C fimbriae, but only $47 \%$ of the isolates expressed S-specific binding properties. Except for one strain (RZ458; 06:K2:H1/OMP4), all isolates expressing S-specific binding (Sfa) were also positive in CLIE for identification of the main peptide subunit of $S$ fimbriae (SfaA) and spot tests using monoclonal antibody mAbA1 which is specific for the $S$ adhesin (SfaS, see Materials and methods). Fimbriae with S-specific binding activity were found on isolates of serotypes $06: \mathrm{K}_{14}: \mathrm{H}^{-}, 06: \mathrm{K}^{2}: \mathrm{H}^{-}, 06: \mathrm{K}^{+}: \mathrm{H}^{-}$and $06: \mathrm{K}^{+}: \mathrm{H} 31$. All these isolates had two fimbrial peptides with apparent molecular weights of 17.2 and 16.2 $\mathrm{kDa}$ by SDS-PAGE, but only the $06: \mathrm{K}^{4} 4: \mathrm{H}^{-}$and $06: \mathrm{K}^{+}: \mathrm{H} 31 / \mathrm{H}^{-}$strains of this group had strongly reactive fimbrial antigens of type F12/1. None of the S-fimbriated $06: \mathrm{K} 2: \mathrm{H}^{-}$isolates reacted with any of the $\mathrm{P}$ fimbrial antisera used. The presence of sfa/foc coding sequences was detected not only among these serotypes but also in $P$-fimbriated isolates, which were shown to express F1C fimbriae, which are highly related to $S$-fimbriae at the genetic level. ${ }^{17.18}$

Type 1 fimbriae. As indicated in Table 1 for type 1 fimbrial expression, the phenotype is in total agreement with the genotype in all strains.

Hemolysin. $92 \%$ of the strains were hemolytic and generally carried the corresponding genes. Three strains of serotypes $06: \mathrm{K} 2: \mathrm{H}^{-}$and $06: \mathrm{K}^{\prime}: \mathrm{H}^{-}$were non-hemolytic and also gave no hybridization signal.

Aerobactin. Aerobactin production was detected in $36 \%$ of the isolates, and all of these strains carry the aer gene clusters. Aerobactin-positive strains were particularly common among isolates of serotypes 06:K2:H1/OMP1 and O6: $\mathrm{K}^{-}: \mathrm{H} 1 / \mathrm{OMP}$.

Combination of virulence factors as basis for clonal classification. The data in Table 1 show an obvious correlation between virulence patterns and the $06: \mathrm{K}: \mathrm{H}$ serotype, and it becomes stronger if the OMPs of the isolates are also taken into account. Among the analysed 06 strains, 16 out of 36 were assigned to membrane patterns 1 or 4 and yielded positive hybridization results with the pap, fim, aer probes, with three exceptions in each case, to the sfa/foc-and $h / y$-specific gene probes.

A total of $17 E$. coli 06 strains which were non-motile or H31 and had membrane pattern 2 or 6 , carried the sfa/foc, fim and hly gene clusters and expressed the corresponding phenotypic properties. However, these strains were always negative in hybridization tests with the aer gene probe. Moreover, we found that $E$. coli strains of serotype $06: \mathrm{K} 53: \mathrm{H} 1$ were not distinguishable from $06: \mathrm{K} 13: \mathrm{H} 1$ isolates by all 


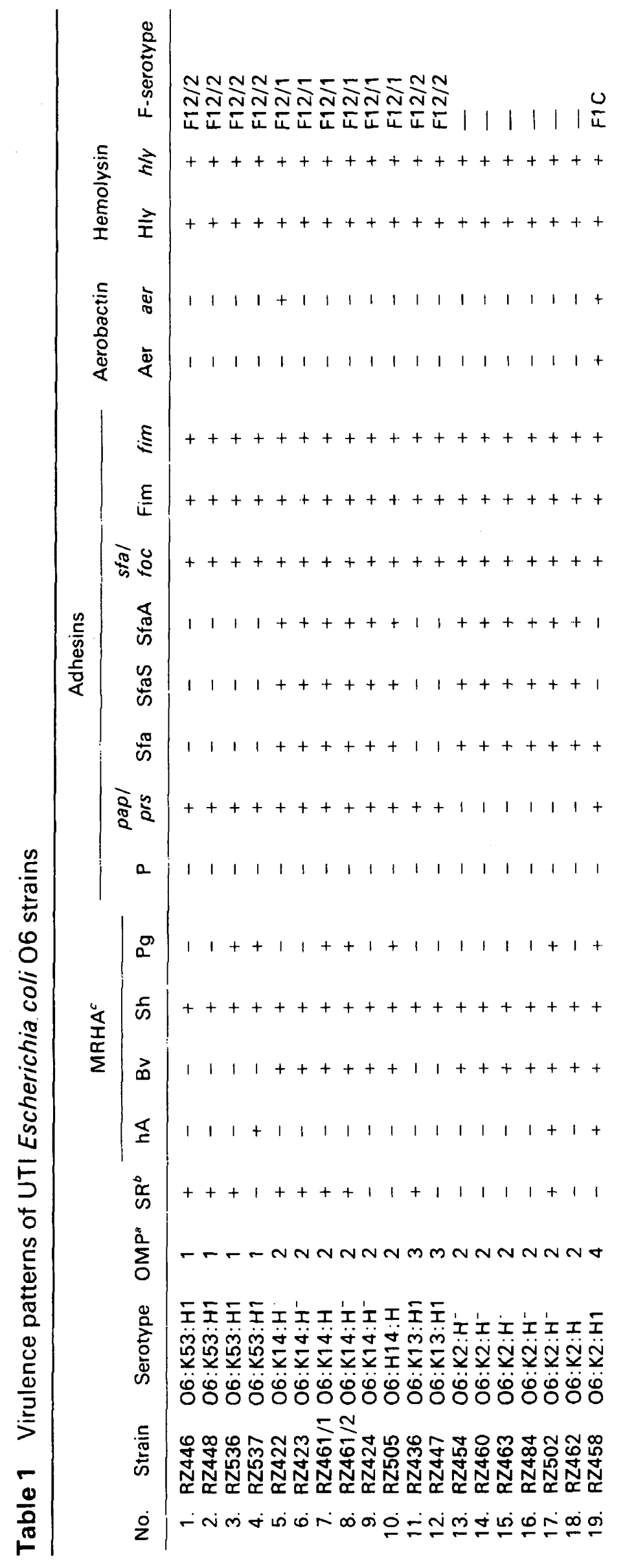




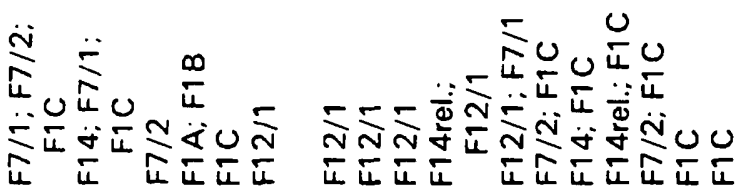

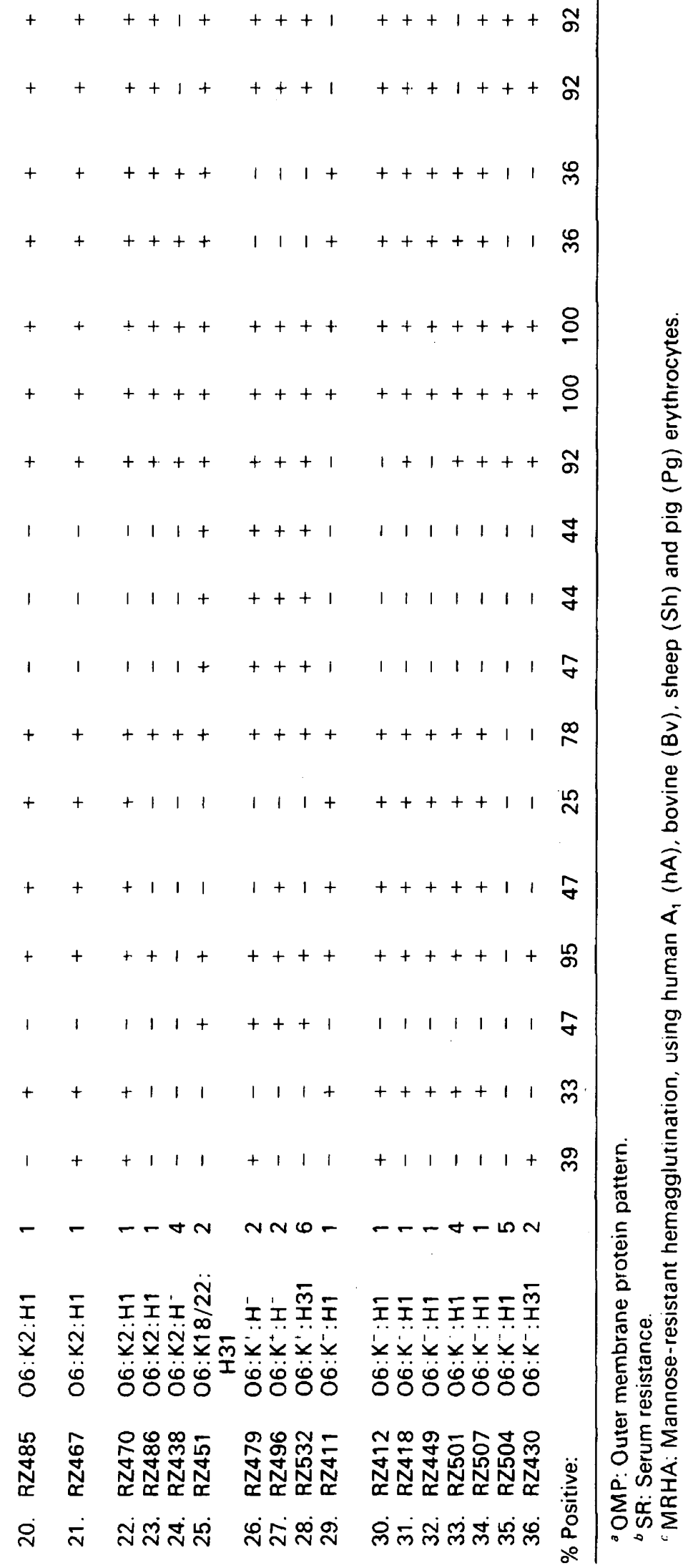


phenotypic and genotypic characteristics, although they differed in their outer membrane protein pattern.

\section{Restriction fragment length polymorphism (RFLP)}

For further analysis, genomic DNA of 20 representative strains was isolated and cleaved with $X b a \mathrm{l}$, which infrequently cuts $E$. coli DNA. The fragments were separated by PFGE and the restriction fragment patterns were compared (Fig. 1a). The two $06: \mathrm{K} 53: \mathrm{H} 1$ isolates (Fig. 1a, lanes 3,4 ) seem to be identical because they had many fragments in common, whereas the two other strains of this serotype (lanes 1,2 ) differed from them and from each other. Similarity of restriction fragment patterns was also found among the $06: \mathrm{K}_{14}: \mathrm{H}^{-}$(Fig. $1 \mathrm{a}$, lanes $5-9,20$ ) and the $06: \mathrm{K}^{2}: \mathrm{H}^{-}$strains (Fig. 1a, lanes 10-13, 19), but the profiles of these groups differed from each other. Sometimes identical profiles (lanes 6,8 or 12,13) were found in strains of the same serotype, which were isolated from different patients. In contrast, markedly different $X$ bal patterns were observed among the five 06:K2: H1 strains (Fig. 1a, lanes 14-18); only the three isolates expressing $P$-specific receptor binding (lanes $14,15,17$ ) share some common fragments. After Sfil cleavage, similar results were obtained (data not shown).

\section{DNA long range mapping using virulence associated gene probes}

In order to assign the specific virulence gene clusters to definite $X b a l$ fragments, Southern hybridizations were carried out using the same DNA probes as used for the DNA-DNA dot blots (Fig. 1). The results are summarized in Fig. 2. It can be seen that not only the $X b a \mid$ profile, but also the hybridization pattern, is highly heterogeneous between strains of different 06:K:H serotypes. Strains of the same serotype which are related by the $X b a l$ pattern also show identical hybridization patterns, with few exceptions. The strains of serotype 06: $\mathrm{K} 2: \mathrm{H} 1$ sharing only few common fragments (lanes 14-18) also displayed some kind of different hybridization patterns. It can be concluded that relatedness of strains also is reflected by the $X b a \mid$ hybridization patterns using virulence associated gene probes.

The hybridization data further show that in some isolates two different fragments were detected by one particular gene probe. Especially, all the $06: \mathrm{K}_{14}: \mathrm{H}^{-}$strains (lanes 5-9, 20) display two fragments using the pap gene probe (Fig. 1c) and concomittantly one of these fragments also hybridized to the $h / y$ probe (Fig. $1 \mathrm{~b}$ ). These data might argue for the presence of two different gene clusters of $P$ fimbriae, from which one is in vicinity to the hly determinants. Similar results were obtained for strain RZ467 (O6:K2:H1) (lanes 15, Fig. 1b,c). On the other hand, the 06:K53 strains RZ536 and RZ537 (lanes 3,4) hybridized in two fragments with hly (Fig. 1b) and displayed hybridization with the pap probes in only one of these fragments (Fig. 1c), but hybridized with the sfa probe (Fig. 1d) to the other hly band. In these strains, a linkage of $h l y$-pap and $h / y-s f a / f o c$ might exist. Also, these two strains exhibited another band with the sfa probe, but distinct from that of the hly specific fragments. Two different bands hybridizing to sfa/foc were also seen in some other strains (lanes $2,10,12,13,16,19)$, which might reflect two copies of these gene clusters.

Fig. 1 (Opposite). Xbal genomic profile of $E$. coli 06 strains obtained by pulsed field gel electrophoresis (a) and Southern hybridization to $h / y(b)$, pap (c), sfa/foc (d) and aer (e) specific gene probes. Strains are as follows (cf. Table 1): (1) RZ446; (2) RZ448; (3) RZ536; (4) RZ537; (5) RZ422; (6) RZ423; (7) RZ461/1; (8) RZ424; (9) RZ505; (10) RZ454; (11) RZ460; (12) RZ484; (13) RZ462; (14) RZ485; (15) RZ467; (16) RZ458; (17) RZ470; (18) RZ486; (19) RZ502; (20) RZ461/2. DNA size standards were lambda concatemers $(L)$, yeast chromosomes $(Y)$ and HindIII cleaved lambda DNA (M) 


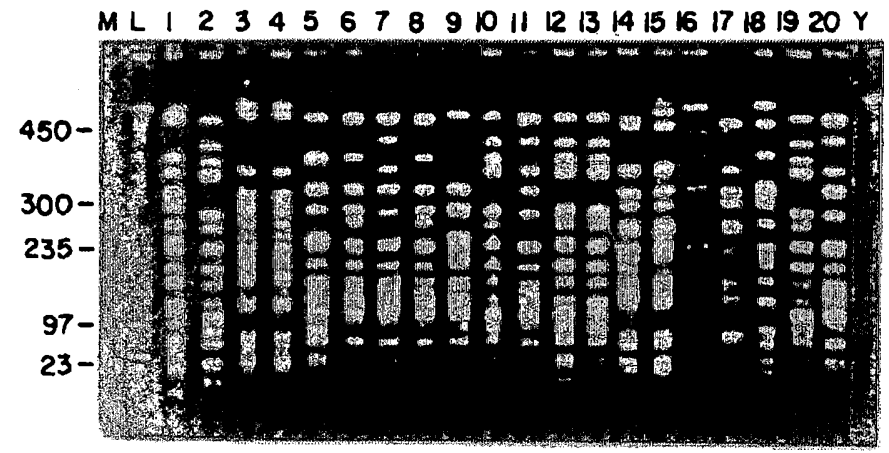

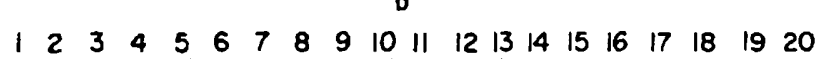

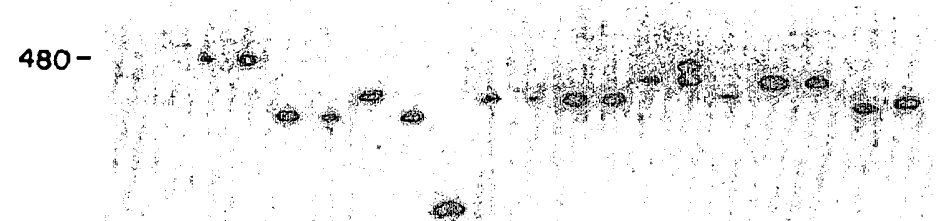

$170-\ldots$

c

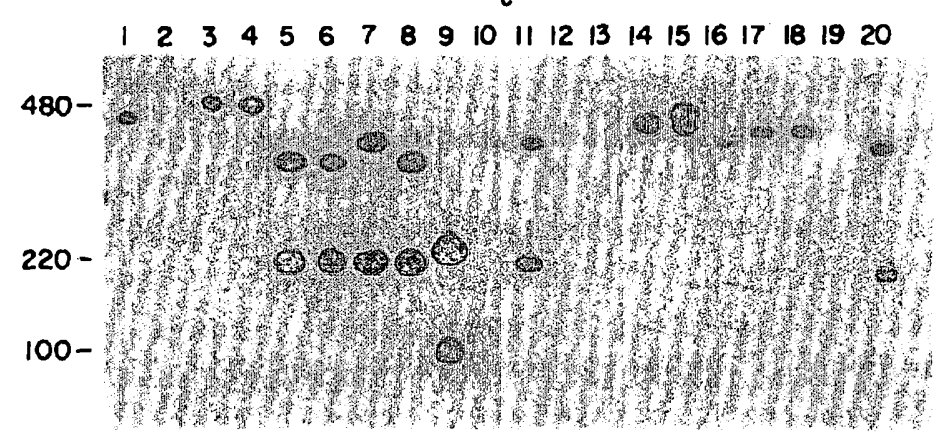

d

$\begin{array}{llllllllllllllllllll}1 & 2 & 3 & 4 & 5 & 6 & 7 & 8 & 9 & 10 & 11 & 12 & 13 & 14 & 15 & 16 & 17 & 18 & 19 & 20\end{array}$

530-
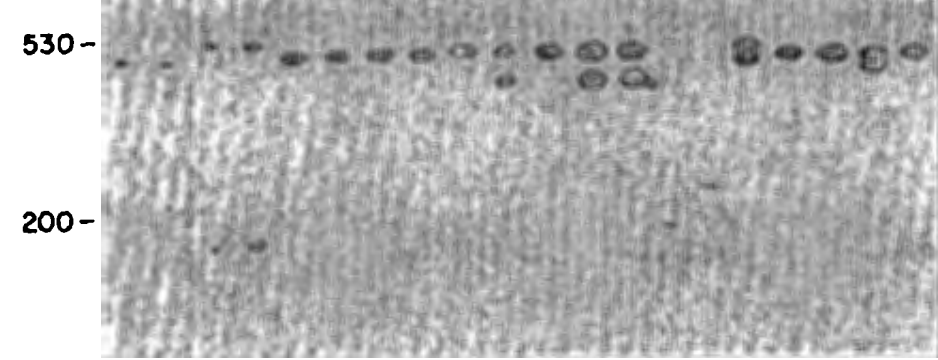

e

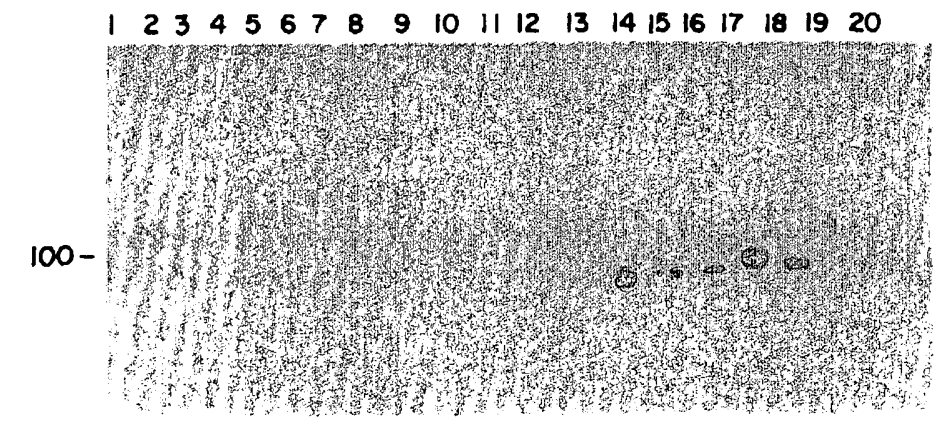




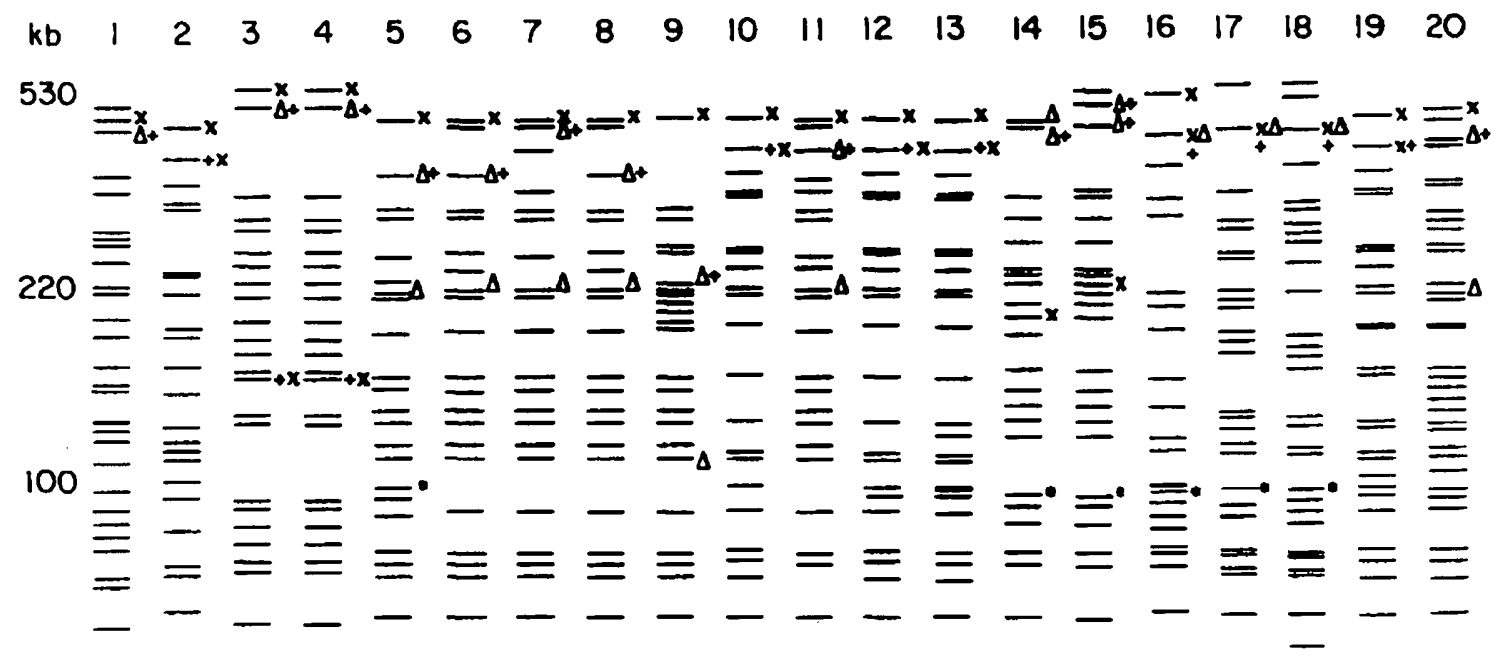

Fig. 2. Interpretation scheme of $X b a \mid$ hybridization patterns of strains analysed in Fig: 1 . The fragments hybridizing to individual gene probes are marked as follows: (*) aer; (+) hly: (A) pap: (x) sfa/foc.

\section{Discussion}

Human uropathogenic strains belong to a limited number of 0 groups, particularly $01,02,04,06,07,016,018$ and $075 .{ }^{5}$ One of the most common $\mathrm{O}$ antigens among these uropathogenic $O$ groups is $E$. coli 06 , which is found in various $06: \mathrm{K}: \mathrm{H}$ combinations, whereas the $\mathrm{H}$ antigen types are restricted to $\mathrm{H} 1{ }^{3.5}$ Examination of the $\mathrm{O}: \mathrm{K}: \mathrm{H}$ serotype strains most commonly found among pyelonephritis strains and sometimes among cystitis strains, for the presence of different virulence factors, revealed an association between virulence factors and $\mathrm{O}: \mathrm{K}: \mathrm{H}$ serotype. ${ }^{2,19}$ Recent studies have shown that strains of the same serotype display genetic and phenotypic diversity, mainly based on the analysis of electrophoretic types (ET). ${ }^{14}$ Also, elaboration of RFLP and the analysis of virulence patterns, especially of $E$. coli 06 strains of extraintestinal source, revealed a highly heterogeneous picture, ${ }^{3,13,15,16}$ but a linkage between the $K$ antigen, type of virulence factors and type of infection could be observed. ${ }^{5.20} 06: \mathrm{K} 13$ strains without $\mathrm{P}$ fimbriae are often isolated from cystitis patients, whereas $P$ fimbriated $06: K 2$ isolates belong to the pyelonephritis-associated clones. ${ }^{20}$

In this report, we present data on the genetic presence and phenotypic expression of fimbrial adhesins, aerobactin and hemolysin among 36 E. coli 06 strains with the capsule types K2, K13, K14, K18/22 and K53. Our material also includes strains without capsule antigens and with capsule types which have not been identified $\left(\mathrm{K}^{+}\right)$. Molecular epidemiological analysis by either phenotypic or genotypic assays has sought to correlate several virulence factors, for example, adhesins and specific patterns of infection. ${ }^{20-23}$ Each of these approaches has intrinsic limitations. Phenotyping may be spurious owing to variations in gene expression, uncertainties as to appropriate receptor-based assays, and the likelihood that most clinical isolates can express several different types of adhesins. On the other hand, colony hybridization studies do not discriminate homologous operons encoding different binding specificities and may be further confounded by other alterations at the nucleotide level. Although a combination of both approaches has been used in recent studies, ${ }^{13.21-24}$ the study described here involved a substantially larger number of exactly serotyped $E$. coli 06 isolates than have been analysed previously, more definitive phenotypic assays, and probing with DNA fragments from several virulence factor genes in DNA-DNA dot blots, as well as in Southern hybridization assays after separation of the $X b a l$ cleaved genomic DNA by PFGE. 
From this study, it can be seen that data primarily elaborated for epidemiological purposes also can be useful for detecting strains with interesting genomic arrangements of virulence factors, such as linkages of virulence determinants. This might build a bridge to the molecular investigation of uropathogenicity. DNA long-range mapping revealed multiple copies of $s f a / f o c$ gene clusters and the determinants encoding $P$ fimbriae and hemolysins, as well as linkage of $h / y$ and $P$ fimbriae determinants and sfa/foc-sequences respectively, in some of the strains in our collection. Multiple copies and linkage of virulence factors seems to be a general phenomenon, as described recently. ${ }^{13,16,25-29}$ The occurrence of such 'virulence clusters' offers the possibility of co-deletions of $h l y$ and P-specific determinants in certain isolates. ${ }^{27}$

The virulence pattern of strains analysed here was homogeneous among isolates of the same $\mathrm{O}: \mathrm{K}: \mathrm{H}$ serotype. Furthermore, the fimbrial serotypes supported the clonal analysis of our $E$. coli 06 isolates. Our data confirm the recent findings ${ }^{13.24}$ that virulence features do reflect close genetic relatedness, however, DNA long-range mapping revealed differences not only among isolates of different serotypes, but also within strains of one serotype. Although, in general, relatedness elaborated by the analysis of virulence factors goes along with similar restriction fragments, the exceptions from the rule should be interpreted carefully in regards to the necessity of molecular tools for clonal analysis. DNA long-range mapping begins to play a major role in epidemiological surveys also, as shown recently, for pathogens other than $E$. coli. ${ }^{30-34}$ However, we emphasize that the combination of both classical and molecular analysis is important to get a complete picture for evaluation of clonality.

\section{Materials and methods}

Bacterial strains and plasmids. All E. coli 06 strains in Table 1 were isolated from patients suffering from either cystitis or pyelonephritis at the Rostock University Hospital. The O6: $\mathrm{K}: \mathrm{H}$ serotypes have already been described, ${ }^{3}$ and the outer membrane patterns of the strains were determined according to Achtman et al. ${ }^{35}$ Fimbriae were analysed serologically by CLIE as previously described. ${ }^{36}$

Plasmids used as source for DNA-probes were described recently (see below).$^{13.24}$ Escherichia coli $\mathrm{K}-12$ strain HB101 was used as a recipient strain for recombinant DNA. ${ }^{37}$ Cultivation was carried out under antibiotic pressure using the following antibiotics: ampicillin, $50 \mu \mathrm{g} / \mathrm{ml}$; chloramphenicol, $20 \mu \mathrm{g} / \mathrm{ml}$; tetracycline, $15 \mu \mathrm{g} / \mathrm{ml}$.

Media, chemicals and enzymes. Bacteria were grown either in Luria Bertani (LB) broth or on LB-agar. Radiochemicals were purchased from NEN Research, Dreieich, Germany. Antibiotics were a gift from Bayer, Leverkusen, Germany. All other chemicals were obtained from Sigma, München, Germany. Restriction enzymes were purchased from Gibco, Eggenstein, Germany.

Adhesion testing. The presence of adhesins was determined by $\mathrm{HA}$ assays using human $\mathrm{A}_{1}$; sheep, bovine and pig erythrocyte suspensions obtained locally with and without $2 \%$ mannose as described elsewhere. ${ }^{3.36}$

$P$-specific adherence was detected by mannose-resistant $H A$ using $P_{1}$ human blood cells and the Gal-Gal specific latex test (PF test) obtained from Orion-Diagnostica (Espoo, Finland). ${ }^{38.39}$ $\mathrm{S}$-specific binding was assayed in an HA-test using bovine erythrocytes incubated with neuraminidase or fetuin as described previously. ${ }^{40}$ Type 1 fimbriation was identified by mannosesensitive agglutination of $S$. cerevisiae cells as already described. ${ }^{6}$

Aerobactin test. Aerobactin production was detected by a cross-feeding bioassay ${ }^{41}$ as described. ${ }^{13}$

Hemolysin production. Nutrient agar plates and $5 \%$ sheep blood were used to test for hemolysin production. Strains producing a clear halo larger than the overlying colony, after overnight culture at $37^{\circ} \mathrm{C}$, were defined as hemolysin-positive. 
Resistance to bactericidal effect of serum. Sensitivity to the bactericidal effect of $75 \%$ pooled normal human serum was tested as described previously. ${ }^{42}$

Spot-test for the reaction of $m A b A 1$ with denaturated fimbriae. A spot-test for the reaction of the $\mathrm{mAbA} 1^{43}$ specific for the $\mathrm{S}$-fimbrial adhesin SfaS was carried out with denaturated fimbriae, as described ${ }^{44}$ Briefly, fimbriae were denaturated by boiling in a buffer containing betamercaptoethanol and SDS. Denaturated fimbriae were spotted on nitrocellulose paper and incubated with the mAb.

Immune complexes were detected by incubation with goat anti-mouse peroxidase conjugate (DAKO, Hamburg, Germany) using diaminobenzidine as a substrate.

SDS-PAGE. The disintegration of fimbriae and their electrophoretic separation on polyacrylamide gels (separating gel $15 \%$, stacking gel $5 \%$ ) according to Laemmli, ${ }^{45}$ has been described elsewhere. ${ }^{40}$

DNA-techniques. Chromosomal DNA was isolated as described. ${ }^{46}$ Plasmid DNA was isolated by the clear lysate method. ${ }^{47}$ DNA fragments were eluted from agarose gels by the freezesqueeze method. ${ }^{48}$ DNA was cleaved with restriction enzymes under appropriate conditions and electrophoresed in $1 \%$ agarose gels. ${ }^{49}$ The Hindlll fragments of lambda DNA were used as a DNA size marker.

Pulsed field gel electrophoresis (PFGE). Chromosomal DNA was prepared in agar plugs as described by Grothues and Tümmler. ${ }^{32}$ Agarose blocks were equilibrated in restriction enzyme buffer, and the chromosomal DNA embedded in the agarose was digested with either Xbal or Sfil. A slice of each insert plug was then sealed into a well of 4-mm-thick horizontal agarose gel and electrophoresed (CHEF DR II, Bio-Rad Laboratories, München, Germany) in $0.5 \times$ Trisborate-EDTA buffer ${ }^{49}$ for $25 \mathrm{~h}$ at $14^{\circ} \mathrm{C}$ and $200 \mathrm{~V}$, with the pulse times increasing from 10 to $40 \mathrm{~s}$. Lambda concatemers (Pharmacia, Freiburg, Germany), yeast chromosomes (S. cerevisiae WAY 5-4A, Biometra, Göttingen, Germany) and Hindlll cleaved lambda DNA were used as size markers.

Gene probes and radioactive labelling. The gene probes used were described recently. ${ }^{13,24}$ After isolation from agarose gels, ${ }^{48}$ the DNA fragments were radioactively labelled by the method of Feinberg and Vogelstein ${ }^{50}$ using a random priming kit purchased from Boehringer, Mannheim, Germany.

The pap specific probe was a $4.4 \mathrm{~kb}$ Hindlll fragment isolated from the plasmid pRHU845 $\left(T c^{\prime}\right){ }^{51}$ It has been shown that this probe is also specific for the prs gene cluster coding for $P$ related adhesins. ${ }^{7}$ A $1.8 \mathrm{~kb}$ Clal-EcoRI fragment from the recombinant DNA pANN801-13 $\left(A p^{\prime}\right)$ was used as an sfa/foc specific DNA probe. ${ }^{40}$ This fragment was also subcloned into pBR322, to produce plasmid pANN801-21 (Ap'). This probe also detects foc specific sequences, encoding F1C fimbriae. ${ }^{17}$ The specific DNA probe for type 1 fimbriae gene clusters consisted of the $6.0 \mathrm{~kb}$ Pst l fragment of plasmid pPKL4 $\left(A p^{\prime}\right) .^{52}$ The aerobactin specific probe was a $7.0 \mathrm{~kb}$ HindllI-Eco Rl fragment of plasmid pRG12 $\left(\mathrm{Ap}^{\prime}\right) .^{53}$ The $3.2 \mathrm{~kb}$ Hindlll fragment representing the insert DNA of plasmid pANN215 $\left(\mathrm{Cm}^{\prime}\right)$ was used as an $h / y$ specific probe. Plasmid pANN215 is derived from the wild-type plasmid pHly1 $52 .{ }^{54}$

Colony-dot hybridization. The colony-dot hybridization procedure described by Maniatis et al. ${ }^{49}$ was used for rapid detection of specific virulence factors in the genomes of strains.

Southern hybridization. The transfer of DNA from agarose gels to nitrocellulose paper and the washing and autoradiography of the filters were performed as described earlier. ${ }^{49,55}$ The filters were hybridized in $50 \%$ formamide for $24 \mathrm{~h}$ at $42^{\circ} \mathrm{C}$.

The authors wish to thank B. Becziczka (Rostock) and M. Schmittroth (Würzburg) for expert technical assistance. K. Jann (Freiburg) is acknowledged for supplying monoclonal antibody mAb A1. We thank L. Phillips (Würzburg) for critical reading of the manuscript and $H$. Kurz (Würzburg) for editorial assistance. The work was supported by the Deutsche Forschungsgemeinschaft (DFG Ha 1434/1-7). 


\section{References}

1. Rubin RH, Tolkott-Rubin NE, Cotran RS. Urinary tract infection, pyelonephritis, and reflux nephropathy. In: Brenner BM, Rector FC, eds. The kidney. Philadelphia: WB Saunders, 1986; 1058-141.

2. Svanborg-Eden C, de Man P. Bacterial virulence in urinary tract infection. Infect Dis Clin N Am 1987; 1: $731-50$.

3. Zingler G, Schmidt G, Orskov I, Orskov F, Falkenhagen U, Naumann G. K-Antigen identification, hemolysin production, and hemagglutination types of Escherichia coli 06 strains isolated from patients with urinary tract infections. Zentralbl Bakteriol 1990; 274: 372-81.

4. Falkenhagen U, Zingler G, Naumann G. Serum resistance in different serotypes of Escherichia coli. Zentralbl Bakteriol 1991; 275: 216-22.

5. Orskov I, Orskov F. Escherichia coli in extra-intestinal infections. J Hyg Cam 1985; 95: 551-75.

6. Korhonen TK. Yeast cell agglutination by purified enterobacterial pili. FEMS Microbiol Lett 1979; 6 : 421-5.

7. Lund B, Marklund B-I, Strömberg N, Lindberg F, Karlsson K-A, Normark S. Uropathogenic Escherichia coli can express serologically identical pili of different receptor specificities. Mol Microbiol 1988; 2 : 255-63.

8. Parkkinen J, Rogers GN, Korhonen T, Dahr W, Finne J. Identification of the O-linked sialyloligosaccharides of glycophorin $A$ as the erythrocyte receptors for S-fimbriated Escherichia coli. Infect Immun 1986; 54: 37-42.

9. Parkkinen J, Finne J, Achtman M, Väisänen V, Korhonen TK. Escherichia coli strains binding neuramyl ß-2-3-galactosides. Biochem Biophys Res Commun 1983; 111: 456-61.

10. Van Die I, van Geffen R, Hoekstra W, Bergmans H. Type $1 \mathrm{C}$ fimbriae of a uropathogenic Escherichia coli strain: cloning and characterization of the genes involved in the expression of the $1 \mathrm{C}$ antigen and nucleotide sequence of the subunit gene. Gene 1985; 34: 187-96.

11. Virkola R, Westerlund B, Holthöfer H, Parkkinen J, Kekomäki M, Korhonen TK. Binding characteristics of Escherichia coli adhesins in human urinary bladder. Infect Immun 1988; 56: 2615-22.

12. Marre R, Kreft B, Hacker J. Genetically engineered S- and F1C-fimbriae differ in their contribution to adherence of Escherichia coli to cultured renal tubulus cells. Infect Immun 1990; 58: 3434-7.

13. Blum G, Ott M, Cross A, Hacker J. Virulence determinants of Escherichia coli 06 extraintestinal isolates analysed by Southern hybridizations and DNA long range mapping techniques. Microb Pathogen 1991; 10: 127-36.

14. Caugant DA, Levin BR, Orskov I, Orskov F, Svanborg-Eden C, Selander RK. Genetic diversity in relation to serotype in Escherichia coli. Infect Immun 1985; 49: 407-13.

15. Korhonen TK, Valtonen MV, Parkkinen J et al. Serotypes, hemolysin production, and receptor recognition of Escherichia coli strains associated with neonatal sepsis and meningitis. Infect Immun 1985; 48: 486-91.

16. Plos K, Hull SI, Hull RA et al. Distribution of the P-associated-pilus ( $\rho a p$ ) region among Escherichia coli from natural sources: evidence for horizontal gene transfer. Infect Immun 1989; 57: 1604-11.

17. Ott M, Hoschützky H, Jann K, van Die I, Hacker J. Gene clusters for S fimbrial adhesin (sfa) and F1C fimbriae $(f o c)$ of Escherichia coli: comparative aspects of structure and function. J Bacteriol 1988; 170: 3983-90.

18. Ott M, Schmoll T, Goebel W, van Die I, Hacker J. Comparison of the genetic determinant coding for the S-fimbrial adhesin (sfa) of Escherichia coli to other chromosomally encoded fimbrial determinants. Infect Immun 1987; 55: 1940-3.

19. Achtman M, Pluschke G. Clonal analysis of descent and virulence among selected Escherichia coli. Annu Rev Microbiol 1986; 40: 185-210.

20. Väisänen Rhen V, Elo J, Väisänen E et al. P-fimbriated clones among uropathogenic Escherichia coli strains. Infect Immun 1984; 43: 149-55.

21. Arthur $M$, Johnson $C E$, Rubin $\mathrm{RH}$ et al. Molecular epidemiology of adhesin and hemolysin virulence factors among uropathogenic Escherichia coli. Infect Immun 1989; 57: 303-13.

22. Archambaud M, Courcoux P, Ouin V, Chabanon G, Labigne-Roussel A. Phenotypic and genotypic assays for the detection and identification of adhesins from pyelonephritic Escherichia coli. Ann Microbiol (Paris) 1988; 139: 557-73.

23. Archambaud M, Courcoux $P$, Labigne-Roussel A. Detection by molecular hybridization of pap, afa and sfa adherence systems in Escherichia coli strains associated with urinary and enteral infections. Ann Microbiol (Paris) 1988; 139: 575-88.

24. Ott $M, B e n d e r ~ L, B l u m ~ G$ et al. Virulence patterns and long-range genetic mapping of extraintestinal Escherichia coli K1, K5, and K100 isolates: use of pulsed-field gel electrophoresis. Infect Immun 1991: 59: 2664-72.

25. Arthur M, Campanelli $C$, Arbeit RD et al. Structure and copy number of gene clusters related to the pap P-adhesin operon of uropathogenic Escherichia coli. Infect Immun 1989; 57: 314-21.

26. Hacker J. Bender L, Ott M et al. Deletions of chromosomal regions coding for fimbriae and hemolysin occur in vitro and in vivo in various extraintestinal Escherichia coli isolates. Microb Pathogen 1990; 8 : 213-25.

27. Hacker J, Ott M, Blum G et al. Genetics of Escherichia coli uropathogenicity: Analysis of the O6: $\mathrm{K} 15: \mathrm{H} 31$ isolate 536. Zentralbl Bakteriol 1992; 276: 165-75. 
28. Hull SI, Bieler S, Hull RA. Restriction fragment length polymorphism and multiple copies of DNA sequences homologous with probes for $P$ fimbriae and hemolysin genes among uropathogenic Escherichia coli. Can J Microbiol 1988; 34: 307-11.

29. Plos K, Carter T, Hull S, Hull R, Svanborg-Eden C. Frequency and organization of pap homologous DNA in relation to clinical origin of uropathogenic Escherichia coli. J Infect Dis 1990; 161: 518-24.

30. Arbeit RD, Arthur M. Dunn R, Kim C, Selander RK, Goldstein R. Resolution of recent evolutionary divergence among Escherichia coli from related lineages: the application of pulsed field electrophoresis to molecular epidemiology. J Infect Dis 1990; 161: 230-5.

31. Ott M, Bender L. Marre R, Hacker J. Pulsed field electrophoresis of genomic restriction fragments for the detection of nosocomial Legionel/a pneumophila in hospital water supplies. J Clin Microbiol 1991; 29: 813-5.

32. Grothues D, Tümmler B. Genome analysis of Pseudomonas aeruginosa by field inversion gel electrophoresis. FEMS Microbiol Lett 1987; 48: 419-22.

33. Tschäpe $H$, Bender L, Ott M, Wittig W. Hacker J. Restriction fragment length polymorphism and virulence pattern of the veterinary pathogen Escherichia coli 0139: K82: H1. Zentralbl Bakteriol 1992; 276: $264-72$.

34. Lück PC, Bender L, Ott M, Helbig JH, Hacker J. Analysis of Legionella pneumophila serogroup 6 strains, isolated over a three-year period from a hospital warm water supply by using genomic long range mapping techniques and monoclonal antibodies. Appl Environ Microbiol 1991; 57: 3226-31.

35. Achtman M, Mercer A, Kusecek B et al. Six widespread bacterial clones among Escherichia coli K1 isolates. Infect Immun 1983; 39: 315-35.

36. Orskov I, Orskov F. Serology of Escherichia coli fimbriae. Prog Allergy 1983; 33: 80-105.

37. Boyer HW, Roulland-Dussoix D. A complementation analysis of the restriction and modification of DNA in Escherichia coli. J Mol Biol 1969; 41: 459-72.

38. De Man P. Cedergren B, Enerbäck $S$ et al. Receptor-specific agglutination tests for detection of bacteria that bind globoseries glycolipids. J Clin Microbiol 1987; 25: 401-6.

39. De Man P, Cläeson I, Johanson I-M, Jodal U, Svanborg-Eden C. Bacterial attachment as a predictor of renal abnormalities in boys with urinary tract infection. J Pediatr 1989; 115: 915-22.

40. Hacker J, Schmidt G, Hughes C, Knapp S, Marget M, Goebel W. Cloning and characterization of genes involved in the production of mannose-resistant, neuraminidase-susceptible (X) fimbriae from a uropathogenic 06:K15:H31 Escherichia coli strain. Infect Immun 1985; 47: 434-40.

41. Braun V, Gross R, Köster W, Zimmermann L. Plasmid and chromosomal mutants in the iron (III)aerobactin transport system of Escherichia coli. Use of Streptonigrin for selection. Mol Gen Genet 1983; 192: 131-9.

42. Taylor PW, Roberts AP, Gower PE. Evaluation of a technique for the estimation of serum bactericidal activity against gram-negative organisms. Med Lab Technol 1972; 28: 272-9.

43. Moch T, Hoschützky H, Hacker J, Kröncke K-D, Jann K. Isolation and characterization of the $x$-sialylB-2,3-galactosyl-specific adhesin from fimbriated Escherichia coli. Proc Natl Acad Sci USA 1987; 84: $3462-6$

44. De Ree JM, Schwillens $P$, van den Bosch JF. Monoclonal antibodies that recognize the $P$ fimbriae $\mathrm{FT}_{1}, \mathrm{~F}_{2}, \mathrm{F9}$ and $\mathrm{F} 11$ from uropathogenic Escherichia coli. Infect Immun 1985; 50: 900-4.

45. Laemmli UK. Cleavage of structural proteins during the assembly of the head of bacteriophage T4. Nature (London) 1970; 227: 680-5.

46. Berger $H$, Hacker J, Juarez A, Hughes C, Goebel W. Cloning of the chromosomal determinants encoding hemolysin production and mannose-resistant hemagglutination in Escherichia coli. J Bacteriol 1982; 152: 1241-7.

47. Birnboim HC, Doly J. A rapid alkaline extraction procedure for screening recombinant plasmid DNA. Nucleic Acids Res 1979; 7: 1513-23.

48. Thuring RWJ, Sanders JP, Borst P. A freeze-squeeze method for recovering long DNA from agarose gels. Anal Biochem 1975; 66: 213-20.

49. Maniatis T, Fritsch EF, Sambrook S. Molecular cloning: A laboratory manual. Cold Spring Harbor Laboratory, New York: Cold Spring Harbor 1982.

50. Feinberg AP, Vogelstein $B$. A technique for radiolabeling DNA restriction endonuclease fragments to high specificity. Anal Biochem 1983; 132: 6-13.

51. Lund B, Lindberg F, Baga M, Normark S. Globoside-specific adhesins of uropathogenic Escherichia coli are encoded by similar trans-complementable gene clusters. J Bacteriol 1985; 162: 1293-301.

52. Klemm $P$, Christiansen $G$. Three fim genes required for the regulation of length and mediation of adhesin of Escherichia coli type 1 fimbriae. Mol Gen Genet 1987; 208: 439-45.

53. Gross R, Engelbrecht F. Braun V. Identification of the genes and their polypeptide products responsible for aerobactin synthesis by pColV plasmids. Mol Gen Genet 1985; 201 : 204-12.

54. Noegel A, Rdest U, Goebel W. Determination of the functions of hemolysin plasmid pHly 152 of Escherichia coli. J Bacteriol 1981; 145: 233-47.

55. Southern EM. Detection of specific sequences among DNA fragments separated by gel electrophoresis. J Mol Biol 1975; 98: 503-17. 